\title{
EFFECT OF DIFFERENT DOSE OF NITROGEN AND PHOSPHOROUS ON GLADIOLUS YIELD AT ILAM, NEPAL
}

\author{
M. Basnet, S.M. Shakya and S.S. Pant \\ Institute of Agriculture and Animal Science, Tribhuvan University, Nepal
}

\begin{abstract}
An experiment was conducted to assess the effect of different levels of nitrogen and phosphorus on Gladiolus yield of cultivar (cv.) Jester in Ilam municipality-2 Fulgachi, Ilam. The research was conducted at the Department farm of Bachelors of Science in Horticulture and Floriculture Management (B.Sc. HFM), Ilam from April to September 2014. The experiment consisted of twelve treatment combinations laid out in factorial randomized complete block design with three replications. Four levels of nitrogen $0 \mathrm{~kg}, 50 \mathrm{~kg}, 100 \mathrm{~kg}$ and $150 \mathrm{~kg} / \mathrm{ha}$ were experimented as the first factor and three levels of phosphorous $0 \mathrm{~kg}, 50 \mathrm{~kg}$ and $100 \mathrm{~kg} / \mathrm{ha}$ formed were taken as the second factor which comprised of twelve treatment combinations. Nitrogen and phosphorous significantly affected plant height, number of leaves per plant, spike length, days to first cutting, days to last cutting and yield (number of corm per plant) of Gladiolus plant.
\end{abstract}

Keywords: Corm, Gladiolus, nitrogen, phosphorous, yield.

\section{INTRODUCTION}

Floriculture can be a promising enterprise in Nepal especially in hilly and inner plane areas. Flowers are high value crops which give higher income per unit of the growing area than other horticultural crops. Despite a wide range of agroclimatic conditions and several micro-climate pocket areas suitable for several diverse flowers and ornamental plants, a systematic and serious attempt has not been made either by growers or entrepreneurs to develop flori-business to its true potential due to lack of market and specialized production techniques. The flower business was limited to vendor sale till 1991/1992 in Nepal (FAN, 2015).

Gladiolus has been rated as one of the most popular flowers in the world, occupying fourth place after rose, chrysanthemum and carnation in international cut flower trade (Bose and Yadav, 1989; Malla, 1998). There is an increasing demand for the spikes owing to its elegance, beauty and long vase life. The availability of wide range of colours varying from white to dark crimson with long spikes make Gladiolus a dominating feature in cut flower industry (Kumar et al., 1999).

Gladiolus is becoming one of the most important cut-flowers and is commercially cultivated for cut-flower trade. Cut-flowers are the most dominating features in modern floriculture. The year round and regular supply and quality are prime considerations of cut-flowers. Nepalese nurseries supply limited number of cut-flowers and cut-foliages on the seasonal basis. The floriproducts produced in Nepal can meet only $40 \%$ of the domestic demand and $60 \%$ demands are being met by the supplies from India (FAN, 2015; Regmi, 2000).

Different Gladiolus cultivars have varying response to different nutrients in terms of yield and quality of the product. Application of recommended dose of fertilizer have been proven effective and played important role in promoting cut flower and corm production. Soil 
and climate of a particular region are important factors affecting the nutritional requirement of Gladiolus. It also depends on cultivar, size and chemical composition of corms or cormels. Cormels and smaller corms require more fertilizer than larger corms mainly due to their stored reserve and partly to greater feeding ability of the extensive root system produced by large corms (Woltz et al., 1978). Application of $\mathrm{N}, \mathrm{P}$ and $\mathrm{K}$ at 60,50 and $60 \mathrm{~kg} /$ ha respectively was found to be optimum for cormel formation in cv. Spic and Span. The best results were obtained with $7.5 \mathrm{~kg}$ ammonium sulphate, 10 $\mathrm{kg}$ super-phosphate and $10 \mathrm{~kg}$ murate of potash per $100 \mathrm{~m}^{2}$ (Mishra, 1999). Increasing rate of nitrogen in cv. Friendship delayed the time of flowering and increased the spike length, weight and size of corms and number of cormels where as higher rates of phosphorous and potash tended to improve flower quality, cormel growth and corm production (Bhattacharjee, 1981). Similarly, higher rate of nitrogen delayed flowering especially from cormels. The number of cormels decreased with increasing nitrogen. The beneficial effect of fertilizer application with $600 \mathrm{~kg}$ super phosphate, $300 \mathrm{~kg}$ murate of potash and $400 \mathrm{~kg}$ ammonium nitrate resulted in greatest plant height, flower number and flower size (Bose and Yadav, 1989).

This research was done to determine the optimum nutrient levels of $\mathrm{N}$ and $\mathrm{P}$ for Gladiolus cv. Jester in order to enhance the floriculture business by increasing and improving the cut flower and corm yield in farmer's condition which ultimately helps to improve the economic condition of the farmers.

\section{MATERIALS AND METHODS}

The experiment was conducted at the Department of Horticulture and Floriculture Management, Fulgaachi, Ilam from April to September, 2014 with the financial support from Research Unit/
Mahendra Ratna Multiple Campus/Tribhuvan University. Two factors experiment was laid out in a completely randomized block design. Four doses of nitrogen $(0,50,100$ and $150 \mathrm{~kg} / \mathrm{ha})$ and three doses of phosphorous $(0,50$ and $150 \mathrm{~kg} / \mathrm{ha})$ formed twelve treatment combinations which were replicated thrice. The Gladiolus corms were planted at $30 \times 25 \mathrm{~cm}$ on each plot having 5 rows with 4 plants per row on the area of $1.5 \mathrm{~m}^{2}$ accommodating 20 plants/plot. The data were taken from the 6 plants excluding the 14 boarder plants. The Gladiolus corms of Jester variety of $5 \mathrm{~cm}$ diameter were used as the planting material. The variety Jester was selected as it has shown better performance in Ilam. The corms were collected from the local traders at Ilam municipality. The selected corms were treated by dipping them in $0.2 \%$ aqueous solution of bavistin for 30 minutes and were shade dried prior to planting. Dehusking of cormels was done before dipping as it has a pronounced effect on seed germination percentage as husk interferes with cytokinin uptake and prevents the dormancy breaking action of the plant hormone (Salanenka and Taylor, 2006 and Miyoshi and Sato, 1997).

Well decomposed farmyard manure (FYM) per plot was applied at the rate of $25 \mathrm{mt} /$ ha two weeks before planting. Potassium was applied at the rate of $200 \mathrm{~kg} / \mathrm{ha}$ in all plots. Nitrogen and phosphorous were applied at the treatment rate. Half dose of nitrogen and full dose both of phosphorus and potash were applied as basal dose in each treatment. The remaining doses of nitrogen were further splitted into two parts. The first part was top dressed when plant attained four leaf stage and the second at six leaf stage (Singh et al., 1994). Nitrogen was applied through urea $(46 \% \mathrm{~N})$, phosphorus through diammonium phosphate $\left(46 \% \mathrm{P}_{2} \mathrm{O}_{5}\right.$ and $16 \%$ $\mathrm{N})$ and potassium through murate of potash 
$\left(60 \% \mathrm{~K}_{2} \mathrm{O}\right)$ respectively. Remaining part of phosphorous was applied through Single Super Phosphate $(16 \% \mathrm{P})$ as per the treatments.

The collected data were entered in the spread sheet in Microsoft Excel sheet and was analyzed by using MSTAT-C software package. Data were analyzed statistically by performing analysis of variance (Steel and Torrie, 1980) and means were separated Duncan's Multiple Range Test at $5 \%$ level of significance (Gomez and Gomez, 1984).

\section{RESULT AND DISCUSSION}

\section{Plant height and number of leaves per plant}

The plant height of Gladiolus was highest at 150 $\mathrm{kg} \mathrm{N} / \mathrm{ha}$ i.e. $36.00 \mathrm{~cm}$ (45 DAT), $46.0 \mathrm{~cm}(60$ DAT) and $59.0 \mathrm{~cm}(75 \mathrm{DAT})$ and lowest plant height i.e. $34.33 \mathrm{~cm}$ (45 DAT), $43.67 \mathrm{~cm}$ (60 DAT) and $57.33 \mathrm{~cm}$ (75 DAT) was observed at $0 \mathrm{~kg} \mathrm{~N} / \mathrm{ha}$ (table 1). Similarly, highest plant height i.e. $36.25 \mathrm{~cm}$ (45 DAT), $46.50 \mathrm{~cm}$ (60 DAT) and 58.25 (75 DAT) was observed on the phosphorous level of $100 \mathrm{~kg} / \mathrm{ha}$ whereas the lowest plant height i.e. $34.0 \mathrm{~cm}$ (45 DAT), $43.75 \mathrm{~cm}(60 \mathrm{DAT})$ and $57.75 \mathrm{~cm}$ (75 DAT) was observed at $0 \mathrm{~kg} \mathrm{P} / \mathrm{ha}$ at 45,60 , and $75 \mathrm{DAT}$. The increment on plant height with the increment on the nitrogen and phosphorous was also reported by Khan et al. (2012) and Hossain et al. (2011). Anil et al. (2000) reported that growth increased with increasing phosphorous doses. Similarly, Bazwaja et al. (2001) and Shah et al. (1984) also found the similar result with increase on nitrogen and phosphorous.

The number of leaves per plant was significantly the highest at nitrogen level $150 \mathrm{~kg} / \mathrm{ha}$ i.e. 3 (45 DAT), 6.667 (60 DAT) and 8.667 (75 DAT) and the lowest leaf number i.e. 1.667 (45 DAT), 3.667 (60 DAT) and 4.667 (75 DAT) were observed at $0 \mathrm{~kg} \mathrm{~N} / \mathrm{h}$. Similarly, the highest i.e. 2.83 (45 DAT), 6.333 (60 DAT) and 7.583 (75 DAT) was observed on the phosphorous level of $100 \mathrm{~kg} / \mathrm{ha}$ and the lowest height i.e. 1.83 (45 DAT), 4.583 (60 DAT) and 5.583 (75 DAT) $\mathrm{cm}$ was observed at $0 \mathrm{~kg} \mathrm{P} / \mathrm{ha}$ (table 1). The increment on number of leaves per plant with the increment on the nitrogen and phosphorous was also reported by Khan et al. (2012) and Hossain et al. (2011). Increasing nitrogen augmented plant growth and number of leaves per plant on Gladiolus plant (Shah et al., 1984).

Table 1. Effect of nitrogen and phosphorous on plant height of Gladiolus at different days of planting in Gladiolus under different condition.

\begin{tabular}{|c|c|c|c|c|c|c|}
\hline \multirow{2}{*}{ Treatment } & \multicolumn{3}{|c|}{ Plant height $(\mathrm{cm})$} & \multicolumn{3}{c|}{ Number of leaves per plant } \\
\cline { 2 - 7 } & $\begin{array}{c}45 \\
\text { DAT }\end{array}$ & $\begin{array}{c}60 \\
\text { DAT }\end{array}$ & $\begin{array}{c}75 \\
\text { DAT }\end{array}$ & $\begin{array}{c}45 \\
\text { DAT }\end{array}$ & $\begin{array}{c}60 \\
\text { DAT }\end{array}$ & $\begin{array}{c}75 \\
\text { DAT }\end{array}$ \\
\hline \multicolumn{7}{|c|}{ Nitrogen $\left(\mathrm{F}_{\mathrm{g}}\right)$} \\
\hline $\mathrm{N}_{0}$ & $34.33^{\mathrm{c}}$ & $43.67^{\mathrm{c}}$ & $57.33^{\mathrm{c}}$ & $1.667^{\mathrm{d}}$ & $3.667^{\mathrm{d}}$ & $4.667^{\mathrm{d}}$ \\
\hline $\mathrm{N}_{50}$ & $34.67^{\mathrm{b}}$ & $44.67^{\mathrm{b}}$ & $58.00^{\mathrm{b}}$ & $2.667^{\mathrm{b}}$ & $5.667^{\mathrm{c}}$ & $5.667^{\mathrm{c}}$ \\
\hline $\mathrm{N}_{100}$ & $34.57^{\mathrm{b}}$ & $44.0^{\mathrm{b}}$ & $58.33^{\mathrm{b}}$ & $2.0^{\mathrm{c}}$ & $6.0^{\mathrm{b}}$ & $6.667^{\mathrm{b}}$ \\
\hline $\mathrm{N}_{150}$ & $36.00^{\mathrm{a}}$ & $46.0^{\mathrm{a}}$ & $59.0^{\mathrm{a}}$ & $3.0^{\mathrm{a}}$ & $6.667^{\mathrm{a}}$ & $8.667^{\mathrm{a}}$ \\
\hline $\mathrm{LSD}$ & 0.022 & 0.036 & 0.016 & 0.012 & 0.016 & 0.045 \\
\hline $\mathrm{SEM}_{ \pm}$ & 0.005 & 0.001 & 0.045 & 0.007 & 0.005 & 0.007 \\
\hline \multicolumn{7}{|c|}{ Phosphorous $^{\left(\mathrm{F}_{\mathrm{b}}\right)}$} \\
\hline $\mathrm{P}_{0}$ & $34.0^{\mathrm{c}}$ & $43.75^{\mathrm{c}}$ & $57.75^{\mathrm{b}}$ & $1.833^{\mathrm{c}}$ & $4.583^{\mathrm{c}}$ & $5.583^{\mathrm{c}}$ \\
\hline $\mathrm{P}_{50}$ & $35.50^{\mathrm{b}}$ & $45.0^{\mathrm{b}}$ & $57.75^{\mathrm{b}}$ & $2.33^{\mathrm{b}}$ & $5.583^{\mathrm{b}}$ & $6.083^{\mathrm{b}}$ \\
\hline $\mathrm{P}_{100}$ & $36.25^{\mathrm{a}}$ & $46.50^{\mathrm{a}}$ & $58.25^{\mathrm{a}}$ & $2.83^{\mathrm{a}}$ & $6.333^{\mathrm{a}}$ & $7.583^{\mathrm{a}}$ \\
\hline LSD $_{0.05}$ & 0.016 & 0.025 & 0.032 & 0.034 & 0.096 & 0.056 \\
\hline $\mathrm{CV}_{0}$ & 3.8 & 5.4 & 4.4 & 9.1 & 6.5 & 7.1 \\
\hline
\end{tabular}

Means within the column followed by the same letter do not differ significantly by DMRT ( $\mathrm{P}=0.05)$.

\section{Flower spike length, days to first and last cutting}

The flower spike length of Gladiolus was significantly the highest at nitrogen level of 150 $\mathrm{kg} / \mathrm{ha}$ irrespective of the stage of growth i.e. 29 $\mathrm{cm}$ (75 DAT), $56.33 \mathrm{~cm}$ (90 DAT) and $88.67 \mathrm{~cm}$ (105 DAT) and the lowest spike length i.e. 23.0 $\mathrm{cm}$ (75 DAT), $51.67 \mathrm{~cm}$ (90 DAT) and $77.67 \mathrm{~cm}$ (105 DAT) were observed at $0 \mathrm{~kg} \mathrm{~N} / \mathrm{ha}$. Similarly, the highest spike length irrespective of growth stage, i.e. $26.25 \mathrm{~cm}(75 \mathrm{DAT}), 55.0 \mathrm{~cm}(90$ DAT) and $84.75 \mathrm{~cm}$ (105 DAT) was observed 
at the phosphorous level of $100 \mathrm{~kg} / \mathrm{ha}$ whereas, the lowest spike length i.e. $24.50 \mathrm{~cm}$ (75 DAT), $52.75 \mathrm{~cm}$ (90 DAT) and $82.50 \mathrm{~cm}$ (105 DAT) was observed at $0 \mathrm{~kg} \mathrm{P} / \mathrm{ha}$ respectively (table 2). The longest spikes obtained from higher nitrogen level might be due to protoplasm formation, division and elongation of meristem cells, enhancing the biosynthesis of proteins and carbohydrates which lead to enhanced growth (Verma et al., 2000). Similar result was reported by Sehrawat et al., (2003) and Shah et al. (1984). Moreover, Sidhu and Arora (1989) reported that spike length was significantly improved by the application of 20 gram nitrogen per square meter which is equivalent to $200 \mathrm{~kg} \mathrm{~N} / \mathrm{ha}$.

Days to first harvesting of Gladiolus flowers was found to be the earliest at nitrogen level of $0 \mathrm{~kg} /$ ha, i.e., 121.0 days and the most late i.e. 130.0 days at $150 \mathrm{~kg}$ nitrogen per hectare. Similarly, days to first harvesting of Gladiolus flower was found to be the earliest at phosphorus level of 0 $\mathrm{kg} / \mathrm{ha}$, i.e., 123.8 days and the most late i.e. 126.0 days at $100 \mathrm{~kg} \mathrm{P} /$ ha (table 2). Moreover, days to final harvesting of Gladiolus flowers was found to be the earliest at $0 \mathrm{~kg} \mathrm{~N} /$ ha, i.e., 133.7 days and the most late i.e. 142.0 days at $150 \mathrm{~kg} \mathrm{~N} / \mathrm{ha}$. Similarly, days to final harvesting of Gladiolus flower was found to be the earliest at $0 \mathrm{~kg} \mathrm{P} / \mathrm{ha}$, i.e., 130.0 days and the most late i.e. 138.0 days at $100 \mathrm{~kg} \mathrm{P} /$ ha (table 2). Higher level of nitrogen increased vegetative growth thereby delaying reproductive phase of the plant. These results are in line with the findings of Bhattacharjee (1981) who stated that increasing the level of nitrogen and phosphorous advanced the time of flowering thereby lengthening the time for the first and final harvesting of the spikes. Similar results were found by Borrelli (1984), Deswal et al. (1983), Shah et al. (1984) and Sindhu and Arora (1989).

Table 2. Effect of nitrogen and phosphorous on flower spike length, days to first and last harvesting of Gladiolus spike under different condition

\begin{tabular}{|c|c|c|c|c|c|}
\hline \multirow[t]{3}{*}{$\begin{array}{l}\text { Treat- } \\
\text { ment }\end{array}$} & \multicolumn{3}{|c|}{ Flower spike length $(\mathrm{cm})$} & \multicolumn{2}{|c|}{$\begin{array}{c}\text { Days to } \\
\text { harvesting }\end{array}$} \\
\hline & 75 & 90 & 105 & First & Final \\
\hline & DAT & DAT & DAT & & \\
\hline \multicolumn{6}{|c|}{ Nitrogen $\left(\mathrm{F}_{\mathrm{a}}\right)$} \\
\hline $\mathrm{N}_{0}$ & $23.00^{\mathrm{d}}$ & $51.67^{d}$ & $77.67^{\mathrm{d}}$ & $121.7^{\mathrm{d}}$ & $133.7^{\mathrm{d}}$ \\
\hline $\mathrm{N}_{50}^{0}$ & $24.33^{\mathrm{c}}$ & $52.00^{\mathrm{c}}$ & $82.0^{c}$ & $122.3^{\mathrm{c}}$ & $134.3^{\mathrm{c}}$ \\
\hline $\mathrm{N}_{100}$ & $26.00^{b}$ & $55.0^{\mathrm{b}}$ & $86.0^{\mathrm{b}}$ & $125.7^{\mathrm{b}}$ & $137.7^{\mathrm{b}}$ \\
\hline $\mathrm{N}_{150}^{100}$ & $29.00^{\mathrm{a}}$ & $56.33^{\mathrm{a}}$ & $88.67^{\mathrm{a}}$ & $130.0^{\mathrm{a}}$ & $142.0^{\mathrm{a}}$ \\
\hline LSD & 0.018 & 0.098 & 0.064 & 0.018 & 0.058 \\
\hline $\mathrm{SEM} \pm$ & 0.009 & 0.005 & 0.009 & 0.006 & 0.003 \\
\hline \multicolumn{6}{|c|}{ Phosphorous $\left(\mathrm{F}_{b}\right)$} \\
\hline $\mathrm{P}_{0}$ & $24.50^{\mathrm{c}}$ & $52.75^{\mathrm{c}}$ & $82.50^{\circ}$ & $123.8^{\mathrm{c}}$ & $130.0^{c}$ \\
\hline $\mathrm{P}_{50}$ & $26.00^{\mathrm{b}}$ & $53.50^{\mathrm{b}}$ & $83.50^{\mathrm{b}}$ & $125.0^{\mathrm{b}}$ & $132.8^{\mathrm{b}}$ \\
\hline $\mathrm{P}_{100}$ & $26.25^{\mathrm{a}}$ & $55.0^{\mathrm{a}}$ & $84.75^{\mathrm{a}}$ & $126.0^{\mathrm{a}}$ & $138.0^{\mathrm{a}}$ \\
\hline $\operatorname{LSD}_{0.05}$ & 0.036 & 0.063 & 0.045 & 0.073 & 0.018 \\
\hline $\mathrm{CV} \%$ & 10 & 7.2 & 6.5 & 10 & 4.5 \\
\hline
\end{tabular}

Number and weight of corms per plant and diameter of the corm

The number of corms per Gladiolus plant was found to be the highest at $150 \mathrm{~kg} \mathrm{~N} /$ ha i.e. 2.0 and the lowest number i.e. 1.33 at $0 \mathrm{~kg} \mathrm{~N} / \mathrm{ha}$. Similarly, the highest number of corms per plant was found to be highest at $100 \mathrm{~kg} \mathrm{P} /$ ha i.e. 1.90 and the lowest number i.e. 1.75 at $0 \mathrm{~kg} \mathrm{P} / \mathrm{ha}$ (table 3 ). In addition, the weight of the corm per plant was found to be the highest at $150 \mathrm{~kg} \mathrm{~N} /$ ha i.e. $28.43 \mathrm{gm}$ and the lowest weight i.e. 22.3 gm at $0 \mathrm{~kg} \mathrm{~N} / \mathrm{ha}$. Similarly, the highest weight of the corms per plant was found to be at $100 \mathrm{~kg} \mathrm{P} /$ ha i.e. $26.71 \mathrm{gm}$ and the lowest weight i.e. 23.24 $\mathrm{gm}$ at $0 \mathrm{~kg} \mathrm{P} / \mathrm{ha}$. Moreover, the diameter of the corm was found to be highest at $150 \mathrm{~kg} \mathrm{~N} /$ ha i.e. $4.86 \mathrm{~cm}$ and the lowest diameter i.e. $3.8 \mathrm{~cm}$ at $0 \mathrm{~kg} \mathrm{~N} / \mathrm{ha}$. Similarly, the highest corm diameter was found to be at $100 \mathrm{~kg} \mathrm{P} /$ ha i.e. $4.5 \mathrm{~cm}$ and the lowest diameter i.e. 3.1 at $0 \mathrm{~kg} \mathrm{P} /$ ha (table 3). Sehrawat et al. (2003) reported that number and weight of corms per plant and diameter of the corm was significantly influenced by the increment of nitrogen and phosphorous level. Similar results were obtained by Hossain et al. (2011), Pant (2005), Baral et al. (2012), Khan 
et al. (2012) Mishra and Singh (1998) and Mukherjee et al. (1994).

Table 3. Effect of nitrogen and phosphorous on number and weight of the corm per plant and size of the Gladiolus corm under different condition

\begin{tabular}{|c|c|c|c|}
\hline Treatment & $\begin{array}{l}\text { Number } \\
\text { of corms } \\
\text { per plant }\end{array}$ & $\begin{array}{l}\text { Weight of } \\
\text { the corm per } \\
\text { plant }\end{array}$ & $\begin{array}{l}\text { Diameter } \\
\text { of the corm } \\
(\mathrm{cm})\end{array}$ \\
\hline \multicolumn{4}{|c|}{ Nitrogen $\left(F_{2}\right)$} \\
\hline $\mathrm{N}_{0}$ & $1.333^{\mathrm{c}}$ & $22.3^{\mathrm{c}}$ & $3.8^{\mathrm{d}}$ \\
\hline $\mathrm{N}_{50}^{0}$ & $1.667^{\mathrm{b}}$ & $23.66^{\mathrm{c}}$ & $4.13^{\mathrm{c}}$ \\
\hline $\mathrm{N}_{100}^{50}$ & $1.667^{\mathrm{b}}$ & $25.63^{b}$ & $4.38^{\mathrm{b}}$ \\
\hline$N_{150}$ & $2.0^{\mathrm{a}}$ & $28.43^{\mathrm{a}}$ & $4.86^{\mathrm{a}}$ \\
\hline LSD & 0.023 & 1.640 & 0.023 \\
\hline $\mathrm{SEM} \pm$ & 0.007 & 0.559 & 0.007 \\
\hline \multicolumn{4}{|c|}{ Phosphorous $\left(F_{b}\right)$} \\
\hline $\mathrm{P}_{0}$ & $1.750^{\mathrm{b}}$ & $23.24^{\mathrm{c}}$ & $3.1^{\mathrm{c}}$ \\
\hline $\mathrm{P}_{50}$ & $1.750^{\mathrm{b}}$ & $25.07^{b}$ & $4.3^{\mathrm{b}}$ \\
\hline $\mathrm{P}_{100}^{00}$ & $1.90^{\mathrm{a}}$ & $26.71^{\mathrm{a}}$ & $4.5^{\mathrm{a}}$ \\
\hline $\operatorname{LSD}_{0.05}$ & 0.056 & 1.640 & 0.245 \\
\hline $\mathrm{CV} \%$ & 7.4 & 8.4 & 8.4 \\
\hline
\end{tabular}

Means within the column followed by the same letter do not differ significantly by DMRT ( $\mathrm{P}=0.05)$.

\section{CONCLUSIONS}

The plant height, leaf length, flower spike length, diameter, weight and number of corms per plant was found to be highest at $150 \mathrm{~kg} \mathrm{~N} /$ ha and $100 \mathrm{~kg} \mathrm{P} / \mathrm{ha}$. So, it is recommended to use the same rate of fertilizer during commercial cultivation of Gladiolus at Nepalese condition.

\section{ACKNOWLEDGEMENT}

We would like to express our sincere thanks to Research Unit of Mahendra Ratna Multiple Campus, Ilam, Tribhuvan Univeristy for providing financial support and necessary facilities and logistic supports.

\section{REFERENCES}

Anil, S., V.P. Ahlawat, A.K. Gupta and A. Sehrawat (2000). Influence of nitrogen, phosphorous and potassium application on growth, flowering and corm production in Gladiolus. Haryana J. Hortic. Sci., 29(1-2): 71-72.

Baral. S.P., D.R. Baral, D.M. Gautam and U.K. Pun (2012). Influence of Nitrogen on Growth Performance, Cut Flower Characteristics and Corm/Cormel Production of Gladiolus. Nepal Journal of Science and Technology 13(1): 25-31.

Bazwaja, H.S., A.S. Panwa and Y.R. Shulka, (2001). Response of Gladiolus to nitrogen and phosphorus. Indian J. Hot., 14(2): 88-89.

Bhattacharjee, S. K. (1981). Influence of nitrogen, phosphorus, and potash fertilization on flowering and corm production in Gladiolus. Singapore J. Pri. Ind. pp. 23-27.

Borrelli, A (1984). Planting density and nitrogen fertilizing in the cultivation of Gladiolus in summer and autumn. Rivista Della Ortoflorutticolura Italiana 68:201-210.

Bose, T.K. and L.P. Yadav (1989). Gladiolus In: Commercial Flowers. Ed. Naya Prakash Calcutta. pp. 267-350.

Deswal, K. S., V. K. Patil and K. W. Answrwadekar (1983). Nutritional and plant population studies in Gladiolus. Indian J. Hort. 40:254-259.

FAN (2015). Production, packaging, marketing business plan on cut flowers carnation, chrysanthemum, gladioli, rose and tuberose. Business Plan for cut flower Galdiolus. III vol. Floriculture Association of Nepalv(FAN), Kathmandu, Nepal. pp:21.

Gomez, K. A. and A. A. Gomez (1984). Statistics for Agricultural Research. John Wiley and Sons, New York.

Hossain. M.J., M.R. Amin, S. Chaudhary and J. Uddain (2011). Effect of different doses of Phposphorous on the growth, corm and cormel development of Gladiolus. Libyan Agriculture Research Center Journal International 2 (1): 0914.

Khan, F.N., M.M. Rahaman, A.J.M.S. Karim and K.H.Hossain (2012). Effect of nitrogen and potassium on growth and yield of Gladiolus corms. Bangladesh J. Agril. Res. 37(4):607-616.

Kumar A., A. Sood, L.M.S. Palni, and A.K. Gupta (1999). In vitro propagation of Gladiolus 
Effect of Different Dose of...

hybridus Hort synergistic effect of heat shock and sucrose on morphogenesis-micropropagation of Gladiolus. Plant cell tissue organ culture. pp. 105-112.

Mallla, K. J. (1998). Floriculture in Nepal Present Status and Future Scope. In: A.Rai, B.Vaidya and S.D. Manandar (eds.) Souvenir, Vasanta floriculture Trade Fare, 2054, Floriculture Association of Nepal (FAN), Katmandu. pp.4144.

Mishra, P.K. (1999). A new report of root and wilt of Gladiolus caused by Poitrask circonis. Indian Phytopath. pp. 234-237

Misra, R.L. and B. Singh. (1998). Gladiolus. In: Commercial Flowers. (Eds) Bose, T. K. and L. P. Yadav. Naya Prokash, Calcutta, India. pp. 266353.

Mukherjee, S., S.C. Jana and T.K. Chatterjee. (1994). Effect of nitrogen and phosphorus doses on production of flower and corms of Gladiolus. Indian Agriculturist. 38(3):211-213.

Miyoshi, K. and T. Sato. (1997). The effect of kinetin and gibberellin on the germination of dehusked seed of indica and japonica rice (Oryza sativa $L$.) under anaerobic and aerobic conditions. Ann. Bot., 80: 479-483.

Pant. S.S. (2005). Effect of different doses of nitrogen and phosphorous on corm and cormel development of Gladiolus (Gladiolus sp.) cv. American Beauty. J. Inst. Agric. Anim. Sci. 26: 153-157.

Regmi, H. N. 2000. Performance evaluation of Gladiolus varieties with respect to growth, cutflower yield and vase life behaviour of cut spikes in Rampur, Chitwan, Nepal.

Salanenka, Y. A. and A. G. Taylor. 2006. Seed coat permeability and uptake of applied systemic compounds. 4th international symposium on seed, transplant and stand establishment of horticultural crops. Translating seed and seedling physiology into technology. December 3-6. San Antonio, Texas.
Sehrawat, S.K., D.S. Dahiya, S.Singh, and G.S. Rana. (2003). Growth, flowering and corm production in Gladiolus as influenced by NPK application. Haryana J. Hort. Sci.32(3/4): 222-224.

Shah, A., S. D. Lal and J. N. Seth. (1984). Effect of different levels of nitrogen and phosphorus on growth, flowering and corm yield of Gladiolus cv. Vinks Glory. Progressive Horticulture. 16(3/4): 305-307.

Sindhu, G.S. and J.S. Arora. (1989). Response of Gladiolus vars. to nitrogen application. Indian J. Hort. pp. 250-254.

Singh, K. P., K. Sujatha, S. Uma and V. Ramachandran (1994). Growth, flowering, yield of planting material and incidence of corm rot disease in Gladiolus. Indian J. Hort. 51 (4): 408-413.

Steel, R. G. D. and J. H. Torries (1980). Principles and Procedures of Statistics: A Biometrical Approach, pp. 232-51. McGraw Hill Book Co. Inc., New York.

Verma, V.K., O.P. Sehgal and S.R. Shiman (2000). Effect of nitrogen and $\mathrm{GA}_{3}$ on carnation J. Orna. Hort. 3(1):64-69.

Woltz, S.S., R.O. Magie, C. Switkin, P.E. Nelson, and T.A. Toussoum (1978). Gladiolus disease response to pre-storage corm inoculation with Fusarium species. Plant Dis. Rep. 62 :134-137.

(Received 18 Aug 2017, revised accepted 3 Oct 2017) 